\title{
Dietary Supplement
}

National Cancer Institute

\section{Source}

National Cancer Institute. Dietary Supplement. NCI Thesaurus. Code C1505.

Oral preparations containing dietary ing redient(s) intended to supplement the diet.

Dietary ing redients include vitamins, minerals, herbs, amino acids, extracts and metabolites. 